\title{
UTILIZATION OF E-RESOURCES FOR TEACHING AND LEARNING OF PHYSICAL AND HEALTH EDUCATION COURSES IN COLLEGES OF EDUCATION OYO, OYO STATE, NIGERIA
}

\author{
Rasheed, Mutairu Akande ${ }^{1}$ \\ Emmanuel Alayande College of Education, \\ Oyo, Oyo State, \\ Nigeria
}

\begin{abstract}
:
This paper investigated the utilization of e-resources for teaching and learning of physical and health education courses in colleges of education Oyo. The instrument for data collection was a self-developed questionnaire with the modified five points Likert scale. The instrument has three scales with reliability value obtained through Cronbach alpha of 0.82 for Awareness of E-Resources Utilization Scale (AWERUS), 0.80 for Accessibility of E-Resources Scale (AERUS), and 0.69 for Usability of E-Resources Utilization Scale (UERS) through Cronbach alpha statistical tool while the instrument has six (6) items each. The demographic data of the respondents were analyzed with frequency counts and percentages while an inferential statistic of chi-square was used to test the hypotheses at 0.05 alpha level. The finding revealed that awareness, accessibility and usability of electronic resources significantly influence their utilization. Based on the findings the following recommendations were made; That the College management should embark on sensitization and publicity drives by giving more education to both staff and students on the available electronic information resources within the College. That both Academic staff and students be trained with ICT knowledge so as to be ICT compliant and utilize more e-resources.
\end{abstract}

Keywords: utilization, E-resources, courses, teaching and learning

\section{Introduction}

Electronic resources are products of Information and Communication Technology (ICT) which has greatly impacted positively in the area of research as well as for effective teaching and learning. Electronic resources or E-resources is also referred to as electronic information resources which can be seen as an assemblage of various types of relevant information in electronic or digital format (Ukachi, 2013). The term electronic resources

${ }^{1}$ Correspondence: email rashmutakoyee2016@gmail.com 
by Sharma (2009) is said to be library's information materials that are in electronic form which include electronic books (e-books); electronic newspapers (e-newspapers); electronic journals (e-journals) as well as Internet resources. E-resources also consist of databases, magazines, archives, theses, conference papers, government papers, scripts and monographs in an electronic form (Deng, 2010). These resources can be accessed by electronic means like mobile phones, laptops, iPads, computers, among others. It has greatly enhanced access to information resources and has further strengthened the knowledge, leading to the concept of global village. E-resources refers to electronic information resources that can be accessed on the web, on or off campus, (Velmurugan, 2013). Recently, electronic resources have been identified as the major sources for information dissemination in the higher institutions of learning, which includes Colleges of education, Polytechnics, and Universities especially for researchers (Lefuma, 2017). User can get the information on what he or she wants with ease. An electronic resource requires computer access or any electronic product that delivers a collection of data, be it text referring to full-text bases, electronic journals, image collections, other multimedia products and numerical, graphical or time-based, as a commercially available title that has been published with an aim to being marketed. These are more useful due to inherent capabilities for manipulation and searching, providing information access is cheaper to acquiring information resources, savings in storage and maintenance, etc. and sometimes the electronic form is the only alternative. E-resources are used to supplement printed resources as they can be accessed remotely without a physical presence in the College library building and are becoming popular with students and academics. Thanuskodi's (2012) study on e-resource usage by students has revealed that e-resources supplement printed resources but because they can be accessed remotely without a physical presence in the academic library, they are popular with students and are seen as disseminated data for research.

Awareness, accessibility, and usability of E-resources play a major role in enhancing effective teaching and learning of Physical and Health Education (PHE). For effective teaching and learning to take place E-resources must be provided for both lecturers and students in order to have access to various types of resources particularly in their areas of specialization. This will not only widen their knowledge base but also prepare them ahead of the challenges that may face them in the course of teaching and learning processes. A variety of activities that are performed by both academic staff and students in the course of teaching and learning hinged on close interaction with the various information resources in their areas of specialization. These include preparation of course materials, communicating in the language of the discipline, facilitation of learning activities with relevant materials, engaging in elaborate conversation with learners, giving exercises that involve critical thinking to learners, acquisitions of latest skills and techniques in sports and games among others. The researcher affirmed that awareness, accessibility, and usability of E-resources are inseparable factors in determining E-resources utilization (Odunlade, 2017). 
Traditionally, PHE is a discipline that does not rely heavily on written discourse and yet, where multiple representations are needed for the construction of understanding within the broad areas of sport, physical activity, and health technologies are widely used as educational tools; to collect data as a basis for the development of better coaching methods and performance techniques (Lockyer and Patterson 2007). Physical Educators must endeavour to use ICT knowledge if such integration would promote learning within the activity context. However, preliminary observation by the researcher revealed that Academic staff and students in the Department of Physical and Health Education from Colleges of Education in Oyo have not been able to utilize electronic information resources as been expected. It is on this note that the researcher intends to ascertain the utilization of e-resources for effective teaching and learning of physical and health education courses in colleges of education Oyo.

\section{Statement of the Problem}

Teaching and learning had gone beyond classroom experience whereby the lecturer is expected to play active roles from the beginning to the end while students play passive roles. E-resources afford students to have information about their courses at the tips of their fingers. It has been observed that students from the Department of Physical and Health Education are lagging behind their counterparts in other departments in terms of ICT compliance that brought about E-resources. Part of the problems has been attributed to inadequate modern ICT infrastructural facilities in colleges leading to low levels of utilization of electronic information resources by Academic staff and students. Sequel to the above information, it is obvious that to prepare Physical and Health Education teachers on training in Oyo Colleges of Education, so as to meet the demands of a global world, requires complete internet and intranet services in place. There is no gainsaying in the fact that the application of E-resources will enhance the effective teaching and learning of Physical and Health Education in our colleges and in turn resulted into the effective acquisition of the necessary skills and techniques that will enable both Academic staff and students themselves to contribute to the growth, improvement, and development of the nation socially and economically.

\subsection{Hypotheses}

The following hypotheses were tested in this study:

1) Awareness of E-resources will not significantly be its utilization for teaching and learning of Physical and Health Education among Academics staff and students of Colleges of Education Oyo.

2) Accessibility of E-resources will not significantly be its utilization for teaching and learning of Physical and Health Education among Academics staff and students of Colleges of Education Oyo. 
3) Usability of E-resources will not significantly be its utilization for teaching and learning of Physical and Health Education among Academics staff and students of Colleges of Education Oyo.

\section{Methodology}

The descriptive survey research design was adopted for this study. The population for the study consisted of lecturers and students of the Department of Physical and Health Education in both Federal and State Colleges of Education, in Oyo, Oyo state. The sample size for the study was one hundred and fifty-four (154) respondents through Stratified and purposive (total) sampling techniques. The population was stratified into two that is, lecturers and students, thereafter, the students were stratified into three while purposive sampling technique was used for all the respondents. The instrument used for data collection was a self-developed questionnaire which was in two sections (Section A and B). Section A based on demographic data of the respondents, while section B was structured in line with the independent variables of utilization (awareness, accessibility, and usability) as well as the dependent variable of teaching and learning with the modified five points Likert scale of summative rating to show the extent of agreement or disagreement viz: Strongly Agree (SA), Agree (A), Undecided (U) Disagree (D) and Strongly Disagree (SD) with 5, 4, 3, 2 and 1 values respectively. The instrument has three scales with a reliability value of 0.82 for Awareness of E-Resources Utilization Scale (AWERUS), 0.80 for Accessibility of E-Resources Utilization Scale (AERUS) and 0.69 for Usability of E-Resources Utilization Scale (UERS) through Cronbach alpha statistical tool while the instrument has six (6) items each. The demographic data of the respondents were analyzed with frequency counts and percentages while inferential statistic of chisquare was used to test the hypotheses at 0.05 alpha level.

\section{Results}

\subsection{Demographic Characteristics of Respondents}

Table 1: Frequency counts and corresponding percentages showing the institutions distribution of the respondents

\begin{tabular}{|l|c|c|}
\hline Institutions & Lecturers Students Total (Frequency) & Percentage \\
\hline $\begin{array}{l}\text { Federal College of } \\
\text { Education (Special), Oyo }\end{array}$ & $1585=100$ & 64.94 \\
\hline $\begin{array}{l}\text { Emmanuel Alayande } \\
\text { College of Education, Oyo }\end{array}$ & $1143=54$ & 35.06 \\
\hline Total & $26128=154$ & 100.0 \\
\hline
\end{tabular}

The above Table 1 indicated the frequency distribution and the percentage of respondents according to the institutions. The total number of 100 (64.94\%) were respondents from 
Federal College of Education (Special), Oyo while 54 (35.06\%) were from Emmanuel Alayande College of Education, Oyo.

Table 2: Frequency counts and corresponding percentages showing the sex distribution of the respondents

\begin{tabular}{|l|c|c|}
\hline Sex & Frequency & Percentage \\
\hline Male & 62 & 40.3 \\
\hline Female & 92 & 59.7 \\
\hline Total & 154 & 100.0 \\
\hline
\end{tabular}

The above Table 2 indicated the frequency distribution and the percentage of respondents according to sex. The total number of $62(40.3 \%)$ were males while $92(59.7 \%)$ were females. This showed that females were more than males by $30(19.5 \%)$.

Table 3: Frequency counts and corresponding percentages showing the age distribution of the respondents

\begin{tabular}{|l|c|c|}
\hline Age & Frequency & Percentage \\
\hline $16-20$ & 24 & 15.6 \\
\hline $21-25$ & 66 & 42.9 \\
\hline $26-30$ & 22 & 14.3 \\
\hline $31-35$ & 11 & 7.1 \\
\hline $36-40$ & 10 & 6.5 \\
\hline $41-$ Above & 21 & 13.6 \\
\hline Total & 154 & 100.0 \\
\hline
\end{tabular}

The result from Table 3 showed the age distribution of the respondents. 24 (15.6\%) respondents were between age 16-20 years old. 66 (42.9\%) were between the age 21-25 years while $22(14.3 \%)$ were between $26-30$ years old. The table also revealed that 11 (7.1\%) were between age 31-35 years old while 10 (6.5\%) were between 36-40 years old and $21(13.6 \%)$ respondents were between age 41years and above.

Table 4: Frequency counts and corresponding percentages showing the status of the respondents

\begin{tabular}{|l|c|c|}
\hline Status & Frequency & Percentage \\
\hline Lecturers & 26 & 16.9 \\
\hline Students & 128 & 83.1 \\
\hline Total & 154 & 100.0 \\
\hline
\end{tabular}

Table 4 above showed that $26(16.9 \%)$ respondents were Lecturers, while $128(83.1 \%)$ were students. 
Table 5: Level of the students respondents

\begin{tabular}{|l|c|c|}
\hline Level & Frequency & Percentage \\
\hline 100Level & 26 & 20.3 \\
\hline 200Level & 50 & 39.1 \\
\hline 300Level & 52 & 40.6 \\
\hline Total & 128 & 100.0 \\
\hline
\end{tabular}

The results from Table 5 showed that 26 (20.3\%) students were in 100Level, 50 (39.1\%) students were in 200Level while 52 (40.6\%) students were in 300Level.

\subsection{Testing of Hypotheses}

Hypothesis One: Awareness of E-resources will not significantly be its utilization for teaching and learning of Physical and Health Education among Academics staff and students of Colleges of Education Oyo.

Table 5: Awareness of E-resources utilization

\begin{tabular}{|l|c|c|c|c|c|}
\hline \multicolumn{1}{|c|}{ Variable } & N & DF & $X^{2}$ Calc. & $X^{2}$ Crit. & Remarks \\
\hline $\begin{array}{l}\text { Awareness of E-resources utilization } \\
\text { for teaching and learning of PHE }\end{array}$ & 154 & 20 & 59.32 & 31.41 & Sig. \\
\hline$X^{2}$ Calc. Value $=59.32>$ Crit. $X^{2}$ value $=31.41, \mathrm{df} 20, \mathrm{p}<0.05$ \\
\hline
\end{tabular}

Table 5 showed that the calculated value of 59.32 is greater than the critical value of 31.41 at 0.05 alpha level with 20 degrees of freedom. This implies that the hypothesis which stated that awareness of E-resources will not significantly be its utilization for teaching and learning of Physical and Health Education among Academics staff and students of Colleges of Education Oyo is hereby rejected. This translates to the fact that awareness of E-resources influences its utilization for teaching and learning of PHE.

Hypothesis Two: Accessibility of E-resources will not significantly be its utilization for teaching and learning among Academics staff and students of Colleges of Education Oyo

Table 6: Accessibility of E-resources utilization

\begin{tabular}{|l|c|c|c|c|c|}
\hline \multicolumn{1}{|c|}{ Variable } & N & DF & $\mathbf{X}^{2}$ Calc. & $\mathbf{X}^{2}$ Crit. & Remarks \\
\hline $\begin{array}{l}\text { Accessibility of E-resources utilization } \\
\text { for teaching and learning of PHE }\end{array}$ & 154 & 20 & 47.11 & 31.41 & Sig. \\
\hline$X^{2}$ Calc. Value $=47.11>$ Crit. $X^{2}$ value $=31.41, \mathrm{df} 20, \mathrm{p}<0.05$ \\
\hline
\end{tabular}

Table 6 showed that the calculated value of 47.11 is greater than the critical value of 31.41 at 0.05 alpha level with 20 degrees of freedom. This implies that the hypothesis which stated that accessibility of E-resources will not significantly be its utilization for teaching and learning of Physical and Health Education among Academics staff and students of Colleges of Education Oyo is hereby rejected. This translates to the fact that accessibility of E-resources influences its utilization for teaching and learning of PHE. 
Hypothesis Three: Usability of E-resources will not significantly be its utilization for teaching and learning among Academics staff and students of Colleges of Education Oyo

Table 7: Usability of E-resources utilization

\begin{tabular}{|l|c|c|c|c|c|}
\hline \multicolumn{1}{|c|}{ Variable } & N & DF & $\mathbf{X}^{2}$ Calc. & $\mathbf{X}^{\mathbf{2}}$ Crit. & Remarks \\
\hline $\begin{array}{l}\text { Usability of E-resources utilization } \\
\text { for teaching and learning of PHE }\end{array}$ & 154 & 20 & 51.35 & 31.41 & Sig. \\
\hline$X^{2}$ Calc. Value $=51.35>$ Crit. $X^{2}$ value $=31.41, \mathrm{df} 20, \mathrm{p}<0.05$ \\
\hline
\end{tabular}

Table 7 showed that the calculated value of 51.35 is greater than the critical value of 31.41 at 0.05 alpha level with 20 degrees of freedom. This implies that the hypothesis which stated that Usability of E-resources will not significantly be its utilization for teaching and learning of Physical and Health Education among Academics staff and students of Colleges of Education Oyo is hereby rejected. This translates to the fact that usability of E-resources influences its utilization for teaching and learning of PHE.

\section{Discussion}

Evidences from Table 5 revealed that both staff and students are aware of the available e-resources in the Colleges libraries and ICT centres. These include e-books, e-journals, e-newspapers, e-magazines, CD ROM, e-projects, e-lecture notes, e-research reports, online databases, and Internet services. The finding was in line with (Ezema and Ugwu, 2013) who affirmed that students are aware of the available electronic information in their campuses. Similarly, the findings of (Kumar, 2016; Mwantimwa, Elia and NdenjeSichalwe,2017)) support the opinion that most of the academic staff and students in higher learning institutions were aware of e-resources. In fact, promotion activities through their websites, flyers, notice-boards, and information literacy programmes were found to be important avenues for raising awareness among academic staff and researchers.

The findings on Table 6, hypothesis two revealed that staff and students have access to E-resources which was in line with findings of (Obande, Osakwe, Ujakpa, Iyawa, Ikechukwu and Amunkete, 2020) who opined that students to some extent have access to available electronic information resources in Nasarawa State higher institutions. This finding also corroborates with (Ezema and Ugwu, 2013) who attested that students have access to electronic information resources and disagree with (Aina, 2014) who attested that since respondents are not aware of the electronic information resources, this affects the access and use of electronic resources.

The findings in Table 7, hypothesis three revealed that the academic staff and students used e-resources for teaching and learning. The finding is similar to the opinion of (Kumar and Anjaiah, 2017) which stated that the majority of their respondents in their study dependent on e-journals to get needed and relevant information for their course work. The e-journals are helping them very much in their working environment also it is 
revealed that practical uses of e-resources are more important in some courses for the research.

\section{Conclusion}

Based on the results of the findings, it was concluded that awareness, accessibility, and usability of electronic resources significantly influence its utilization on both Academic staff and students of the Department of Physical and Health Education in Colleges of Education Oyo.

\subsection{Recommendations}

That the College management should embark on sensitization and publicity drives by giving more education to both staff and students on the available electronic information resources within the College through workshops, public lectures, posters, flyers, handbills, etc.

That effort should be put in place by each College Management to improve the existing bandwidth and ensure the internet connectivity of all schools within the College to ease congestion of the main college E-resources and make it easily accessible to Academic staff and students. This would no doubt enable the users to have wider access to more current electronic information resources without the restriction of space and time.

That both Academic staff and students be trained with ICT knowledge so as to be ICT compliances and utilize more e-resources.

\section{Conflict of Interest Statement}

The author declares no conflicts of interest.

\section{About the Author}

Senior Lecturer Dr., Emmanuel Alayande College of Education, Nigeria. Research Interests: Sports Organization and Administration (Students with the Special Needs) Participations: International Council for Health, Physical Education, Recreation, Sport and Dance (ICHPER.SD Africa Region), Nigeria Society for sports Management (NSSM), Nigeria (Football) Referee Association (NRA).

\section{References}

Aina R. F. (2014). Awareness, Accessibility and Use of Electronic Databases among Academic Staff of Babcock University Business School. Kuwait. Journal of Business and Management Review 3 (6).

Deng, H. (2010). Emerging Patterns and trends in utilizing electronic resources in a higher 
education environment: An empirical analysis. New Library World, 111(3/4): 87103.

Ezema, C. I. \& Ugwu, C. I. (2013). Electronic theses and dissertations in Nigeria university libraries: Status, challenges and strategies, The Electronic Library 31(4), 493-507

Kumar, M. A. and Anjaiah, M (2017). Knowledge, Access and Effective Use Of EResources by The Students of Kakatiya Institute of Technology and Science (Kits), Warangal, Telangana State-A Case Study. International Journal of Digital Library Services Vol. 7 Issue - 3

Kumar, G. R. (2016). Awareness and use of digital library resources by faculty members of engineering college libraries in Warangal District Telangana: A study. International of research in library science, 2 (2), 188- 200.

Lefuma, S. (2017). Access to and use of Electronic Information Resources in the academic libraries of the Lesotho Library Consortium. Unpublished dissertation submitted to College of Humanities University of Kwazulu-Natal, South Africa.

Lockyer, L., \& Patterson, J. (2007). Technology Use, Technology Views: Anticipating ICT use for Beginning Physical and Health Education Teachers. Issues in Informing Science and Information Technology, Volume 4. University of Wollongong. Wollongong, Australia.

Mwantimwa K., Elia E. and Ndenje-Sichalwe E. (2017). Utilisation of E-Resources to Support Teaching and Research in Higher Learning Institutions, Tanzania. University of Dar es Salaam Library Journal Vol 12, No 2, pp-98-123

Obande, B. O., Osakwe, J., Ujakpa, M. M., Iyawa, G. Ikechukwu, A. O. and Amunkete, K. (2020). Awareness, Accessibility and Usability of E-resources: University Students Perspective. 1st-Africa 2020 Conference Proceedings. Miriam Cunningham and Paul Cunningham (Eds)

Odunlade R. O. (2017). Availability and Accessibility of Information Resources as Predictor of Lecturers' Teaching Effectiveness. Library Philosophy and Practice (e journal). Retrieved from https://digitalcommons.unl.edu/libphilprac/1509/

Sharma, C. (2009). Use and impact of e-resources at Guru Gobind Singh Indraprastha University (India): A case study. Electronic Journal of Academic and Special Librarianship, 10(1): 22-33.

Thanuskodi, S. (2012). Use of E-resources by the Students and Researchers of Faculty of Arts, Annamalai University. International Journal of Library Science, 1(1), 1-7.

Ukachi, N. B. (2013). Accessibility and Students Variables as Correlates of the Use of Electronic Information Resources in University Libraries in South-West, Nigeria. Nsukka: Department of Library and Information Science (Unpublished Theses) Velmurugan V. S. (2013). E-Resources. e-Library Science Research Journal. Vol. 1, Issue 12. 

be applied to their work. Under the terms of this license, no permission is required from the author(s) or publisher for members of the community to copy, distribute, transmit or adapt the article content, providing a proper, prominent and unambiguous attribution to the authors in a manner that makes clear that the materials are being reused under permission of a Creative Commons License. Views, opinions and conclusions expressed in this research article are views, opinions and conclusions of the author(s). Open Access Publishing Group and European Journal of Physical Education and Sport Science shall not be responsible or answerable for any loss, damage or liability caused in relation to/arising out of conflict of interests, copyright violations and inappropriate or inaccurate use of any kind content related or integrated on the research work. All the published works are meeting the Open Access Publishing requirements and can be freely accessed, shared, modified, distributed and used in educational, commercial and non-commercial purposes under a Creative Commons attribution 4.0 International License (CC BY 4.0). 